\title{
Changes in the Fine Structure of Chloroplast and Chloroplast DNA of Peach Leaves during Senescence
}

\author{
Naosuke $\mathrm{N}^{1}{ }^{1}$, Shigeyuki Kawano ${ }^{2}$, Soichi Nakamura ${ }^{2}$ \\ and Tsuneyoshi KurolwA ${ }^{2}$ \\ ${ }^{1}$ College of Agriculture, Meijo University, Tempaku, Nagoya 468 \\ ${ }^{2}$ Department of Cell Biology, National Institute for Basic \\ Biology, Okazaki 444
}

\begin{abstract}
Summary
Anatomical features in the chloroplasts of palisade cells in peach (Prunus persica) leaves during senescence were observed by transmission electron microscopy and epifluorescent microscopy. Changes in the chloroplast DNA (cp-DNA) were examined as were the contents of protein, DNA, RNA and nuclease activity. In chloroplasts, the indications of naturally senescing leaves were characterized by the dilation of the thylakoid system and a decrease in the number of stacked grana. During such changes, chloroplast size was much smaller than those of normal cells and the chloroplast gradually became spherical with the appearance of osmiophilic globuli. In the fully senescent mesophyll cells, the chloroplast envelope ruptured and the plastid contents dispersed throughout the interior of the cell appearing as numerous small empty vesicles. Epifluorescent microscopy with 4'-6-diamidino-2-phenylindole (DAPI) showed that the cp-DNA degraded during leaf senescence and disappeared completely at leaf death. Changes in $\mathrm{cp}$-DNA during leaf senescence and chloroplast degradation were concomitant and correlated with cell nucleus degradation. The protein, DNA, and RNA contents of cells decreased significantly during leaf yellowing. During the decrease in DNA levels in senescing leaves the nuclease from peach leaves required $\mathrm{Zn}^{2+}$ for full activation during senescence at Stage III (yellowish-green leaves), while most nuclease activity required $\mathrm{Ca}^{2+}$ and its activity did not change during leaf senescence.
\end{abstract}

\section{Introduction}

Generally, leaf senescence is accompanied by a loss of chlorophyll and protein $(8,12,16$, $27,32,33)$, an increase in proteolytic activity $(8,12,32,33)$, and changes in nucleic acids $(12,13,16,27)$ and carbohydrate levels $(12)$ in the leaves. In addition, there have been numerous studies pertaining to the fine structure of senescing chloroplasts, detached and attached to plants, including such topics: the marked decrease in size of chloroplast $(1,7,10$, $22,28)$; the increase of many large electrondense globules appearing in the stroma $(1,4$, $7,9,10,22,23)$; the disintegration of grana lamellar structure and the dilation of the thylakoid system $(1,4,7,9,10,22,23,28)$; the rupture of the chloroplast envelope $(4,9,23)$; and the loss of starch grain $(1,33)$. However, Received for publication December 25, 1987. no phenomenon has yet been identified which may be regarded as regulatory in chloroplast degradation during leaf senescence. In particular, there is little information on chloroplast ultrastructural changes during leaf senescence in fruit trees.

A number of papers have been published on the changes in number and content of chloroplast DNA (cp-DNA) per cell and cpDNA behavior in chloroplasts during leaf development $(2,6,11,14,15,18,20,25,26,30)$. As cp-DNA changes morphologically in the process of leaf greeing, we suggest that it is important to know how cp-DNA changes in size and shape during leaf senescence. In Chlamydomonas reinhardtii, the behavior of cp-DNA during chloroplast development and degeneration has been observed by Nakamura et al. (19). However, there is little documentation of cp-DNA at any senescing stage in 
higher plants. Chloroplast degradation during leaf senescence may be accompained by degradation of nuclear DNA, the latter of which has been observed by several researchers (1, 23,28 ).

The present investigation has been concerned with the behavior of cp-DNA during leaf senescence in order to gather information relating to the ultrastructure of the chloroplast. The aim was to establish whether chloroplast degradation was accompanied by biochemical changes in the cells. The protein, DNA, and RNA contents were determined along with nuclease activity.

\section{Materials and Methods}

\section{Plant materials}

Two-year-old potted plants of peach (Prunus persica Sieb. et Zucc. cv. Ohkubo) were used for the experiment. All trees were under full sun until the start of the experiment. Then, the potted plants were transferred on September 1 to a glasshouse in order to prevent leaf drop due to wind since peach leaves drop easily from current season's shoots during senescence. Samples of leaves were taken at the fifth nodal position from the base on the current season's shoots. Leaves at the four different stages of leaf senescence were selected until late November viz., normal green, greenish-yellow, yellowish-green, and completely yellow. The stage of senescence was classified by the content of chlorophyll measured by ethanol extraction (31). Chlorophyll content of each stage is presented in Table 1, classed from green (Stage I) to yellow (Stage IV). In addition, completely yellow and partially dried fallen leaves (Stage V) were collected.

\section{Photomicroscopic observation}

To observe the chloroplast appearance and cp-DNA in the mesophyll cells of palisade layers, the mesophyll tissue was separated by a gentle maceration procedure (14). After 2 to 3 hours, the leaf tissue was teased apart on a slide and the suspension of cells was examined under a photomicroscope. In those chloroplasts exhibiting a face view, the organization and arrangement of cp-DNA in the chloroplasts during senescence were studied with a light microscope using the fluorescent probe 4'-6-diamidino-2-phenylindole (DAPI) (14) which binds specifically to DNA. This enabled visualization of organellar nuclei in cells, using a UV excitation filter $(350 \mathrm{~nm})$ with epifluorescence against low transmitted light.

\section{Electron microscopic observation}

For electron microscopy, sections of leaf tissue were taken from mid-lamellar regions of leaves at each stage of senescence. The selected specimens of leaves in each color step were cut into $1 \times 3 \mathrm{~mm}$ pieces, and fixed at room temperature for 2 hours with $2 \%$ glutaraldehyde in $0.05 \mathrm{M}$ cacodylate buffer ( $\mathrm{pH} 7.2$ ). The samples were then rinsed in the same buffer and postfixed for 2 hours with $2, \% \mathrm{OsO}_{4}$ in the same buffer. The fixed specimens were dehydrated through a graded ethanol-acetone series and were embedded in Spurr resin (29). Thin sections were stained with uranyl acetate followed lead citrate (24) and examined with JEOL $100 \mathrm{CX}$ electron microscopy.

Biochemical analysis and nuclease activity

For biochemical analysis, leaves $(5 \mathrm{~g}$ fresh weight) stored at $-80^{\circ} \mathrm{C}$ were macerated with modified Buffer-S (14) by blender at $0-4^{\circ} \mathrm{C}$. The homogenate was filtered through two layers of gauze to remove large fragments and washed twice with cold $4 \%$ trichloroacetic acid in $80 \%$ acetone-water $(\mathrm{v} / \mathrm{v})$ by centrif. ugation at $3,000 \mathrm{rpm}$ for $5 \mathrm{~min}$. It was then washed twice with $0.25 \mathrm{~N}$ perchloric acid (PCA) and suspended in $0.5 \mathrm{~N} \mathrm{PCA}$ at $70^{\circ} \mathrm{C}$ for $15-20 \mathrm{~min}$. Protein concentration in the extracts was determined by the method of Lowry et al. (17). DNA concentration was determined by the method of Burton (13) and RNA by the orcinol reaction (5). For nuclease activity, leaves (stored at $-80^{\circ} \mathrm{C}$ ) were ground to a fine power in liquid nitrogen using a mortar and pestle, then sonicated for $20 \mathrm{sec}$. Samples were subjected to electrophoresis on

Table 1. Chlorophyll content at different stages of peach leaf senescence.

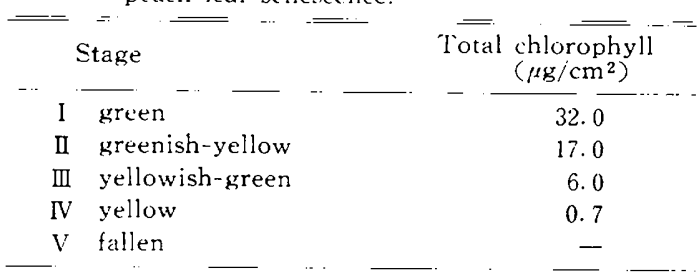




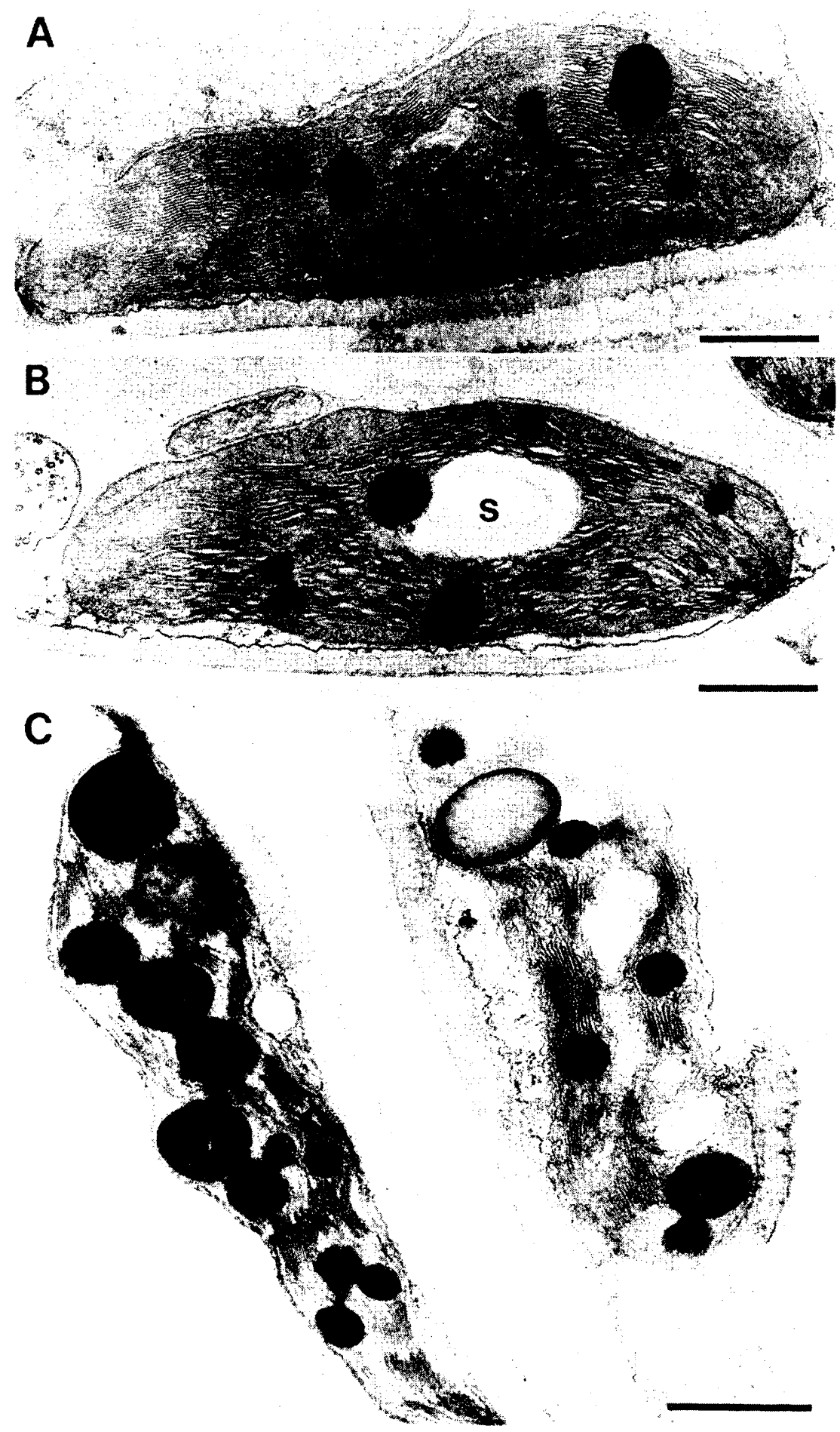

Fig. 1a. Details are given in Fig. 1b. 


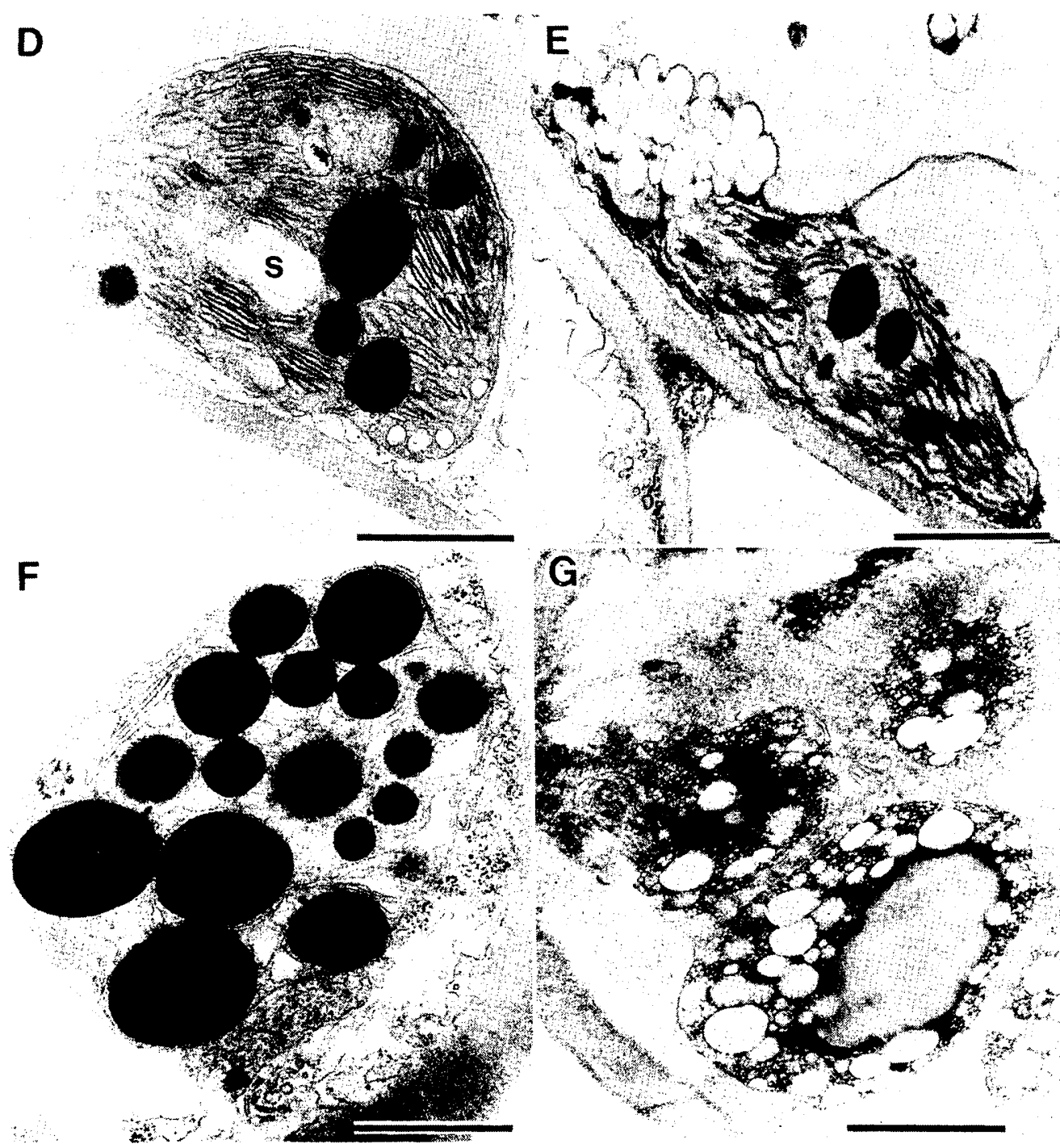

Fig. 1b. Electron micrographs of young peach leaves illustrating chloroplasts at different stages of senescence. A, Stage I (normal green). B, Stage II (greenish-yellow). C and I), Stage III (yellowish-green). E and F, Stage IV (yellow). G, Stage V (fallen leaves, presumably dead). s, starch. Bar $1.0 \mu \mathrm{m}$.

a sodium dodecyl sulfate (SDS)-DNA gel essentially according to the assay method for Chlamydomonas nuclease C (21).

\section{Results and Discussion}

In naturally senescing peach leaves, the first visible change was the yellowing process due to the reduction of chlorophyll content. Table 1 shows the chlorophyll levels in the peach leaves used for this experiment.
The typical ultrastructural appearance of the chloroplast in mesophyll cells at each stage of leaf senescence is shown in Fig. 1 ( $a$ and b) in order to indicate the sequence of senescence. In the chloroplast of green leaves (Stage I, Fig. 1 a-A) normal thylakoid structure and small dense globules were seen. The chloroplast was spindle shaped and about 7-8 $\mu \mathrm{m}$ in length. In cells of the greenish-yellow leaves (Stage II, Fig. 1 a-B), the chloroplasts, 
at the stage at which senescence had just started, were still the similar size to those from nonsenescing leaves, and still contained starch grains. However, the thylakoid structure was slightly loose.

As senescence progressed (Stage III, Fig. $1 \mathrm{a}-\mathrm{C}$, Fig. $1 \mathrm{~b}-\mathrm{D})$, the lamellar system of the chloroplast no longer resembled the normal membrane system; it was disoriented and the membranes of grana and intergrana lamellae were loosely separated. Some characteristic swelling occurred at the terminus of each thylakoid. In some chloroplasts at Stage III, the chloroplast envelope appeared partially disintegrated. Chloroplast size in senescing leaves decreased gradually, as did those in normal green cells and became spherical with the appearance of osmiophilic globuli.

In cells taken from fully yellowed tissues (Stage IV, Fig. $1 \mathrm{~b}-\mathrm{E}, \mathrm{F}$ ) almost all the internal structure of chloroplasts had collapsed, although the chloroplasts still contained residual membranes from the thylakoid system. In some profiles, the chloroplast envelope was discontinuous, and some membrane system, which at times changed into many small membrane vesicles, were dispersed throughout the cell interior, as has been observed by Hurkman (9).

In presumably dead cells numerous small vesicles with empty contents were dispersed in the cytoplasm (Fig. $1 \mathrm{~b}-\mathrm{G}$ ).

During this process, the observations of chloroplast senescence in peach leaves resemble
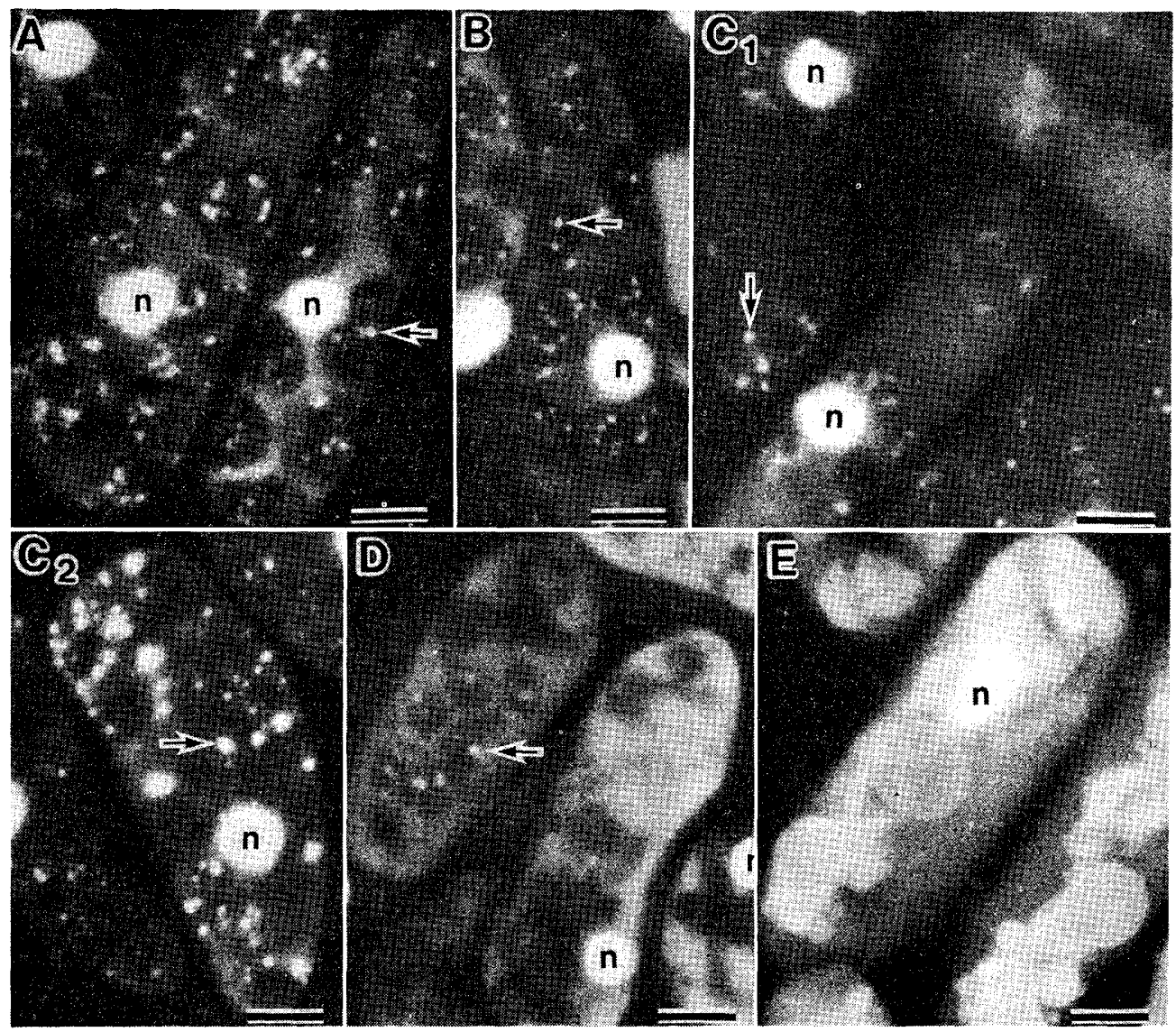

Fig. 2. Fluorescent micrographs reveal a cell containing a central nucleus ( $n$ ), chloroplast DNA (indicated by arrows), after DAPI staining in young peach leaves during senescence. A, Stage I. B, Stage II. C, Stage III. D, Stage IV. E, Stage V. Details are given in Fig. 1b. Bar $5.0 \mu \mathrm{m}$. 
those reported for other species $(1,4,7,9,10)$. In the present results the noticeable feature of chloroplast breakdown occurred at Stage III. The rupture of the chloroplast envelope membrane together with the liberation of the chloroplast contents into the cytoplasm during senescence occurred at the senescence Stage III. Thus, the membraneous barriers were destroyed during cell senescence.

Cp-DNA was examined by fluorescence microscopy on squashed preparations of peach leaves treated with maceration enzymes. Fig. 2 shows typical epifluorescence microscopic images of the cell nuclei and cp-DNA in a series of the above changes in organization and arrangement of cp-DNA.

Stage I (Fig. 2-A). The nucleus and cpDNA were well detected readily in all cells. Cp-DNA glittered clearly in the plastids. At Stage II, the nucleus and cp-DNA were well preserved.

Stage III (Fig. 2- $\mathrm{C}_{1}$ ). 'The intensity of $\mathrm{cp}-$ DNA decreased with the reduction of the membrane and size of chloroplasts (Fig. 1 a$\mathrm{C}, 1 \mathrm{~b}-\mathrm{D})$. The nucleus in some cells was not clear or was not detected by DAPI staining. The chlorophyll content was very low in leaves at stage III, shown in Table 1, and the red emission of the chlorophyll complex activated by UV fluorescence was reduced. Many mobile cp-DNA-like granules, which were stained lightly with DAPI, were detected under the microscope, and in some cells at this stage the cp-DNA presumably aggregated, resulting in a large fluorescent mass at the exterior of chloroplasts (Fig. 2- $\mathrm{C}_{2}$ ). Some chloroplasts persisted even in the cells in which nuclei were not detected. However, in general, the chloroplast degradation was faster in the cells whose nuclear degradation was pronounced.

Stage IV (Fig. 2-D). Central nuclei and cp-DNA markedly reduced in size. However, some cell nuclei and cp-DNA could be detected by eye, even in the completely yellow color leaves. At Stage V (Fig. 2-E), most nuclei and all cp-DNA had disappeared or could not detect with DAPI.

From visual observations, the number, size, and distribution of cp-DNA changed remarkably during chloroplast senescence and this paralleled the ultrastructural changes.

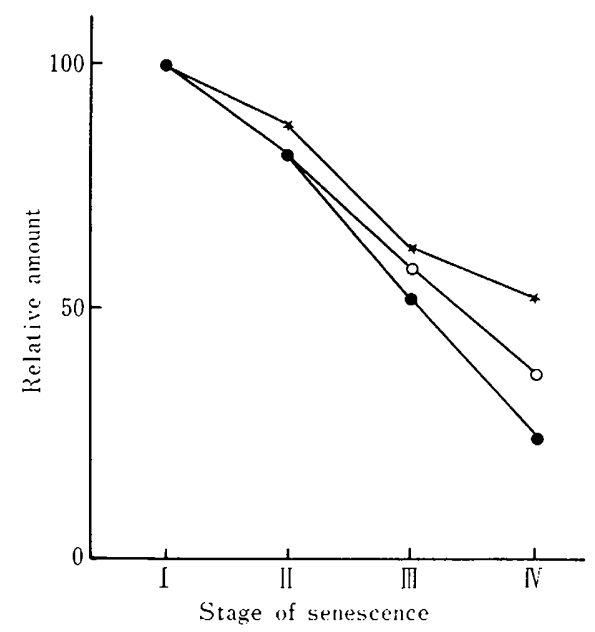

Fig. 3. Relative amounts of protein ( $), \mathrm{DNA}(\mathrm{O})$, RNA $(\star)$ in young peach leaves at different stages of senescence.

Relative concentrations of protein, DNA, and RNA in peach leaves during senescence are shown in Fig. 3. These three biochemical components evidently decreased during leaf senescence. Degradation was fastest with protein and slowest with RNA, in contrast with other papers (27). Although the cell nuclei and $\mathrm{cp}$-DNA diminished dramatically during Stage III, as found by fluorescence microscopy using DAPI, one third of the earliar DNA content was still present.

The loss of DNA from the mesophyll nucleus and cp-DNA (plus unknown contribution of mitochondria content) as principally observed by the DAPI method was also evident in the DNA analysis by the Burton method (3). Nucleus and cp-DNA stained with DAPI almost disappeared from the cell at Stage IV, although chemically DNA could still be demonstrated.

Although protein, DNA, and RNA content of the peach leaves were analyzed, only one enzyme system, nuclease activity, was examined directly since it could be related to DAPI microscopy, and also DNase activity during yellowing process has been reported by Lewington et al. (16).

Ogawa and Kuroiwa (21) reported that $\mathrm{Ca}^{2+}$ dependent nuclease activity in Chlamydomonas reinhardtii was high and that $\mathrm{Mg}^{2+}-, \mathrm{Zn}^{2+}$, and $\mathrm{Mn}^{2+}$-dependent activities were very low 


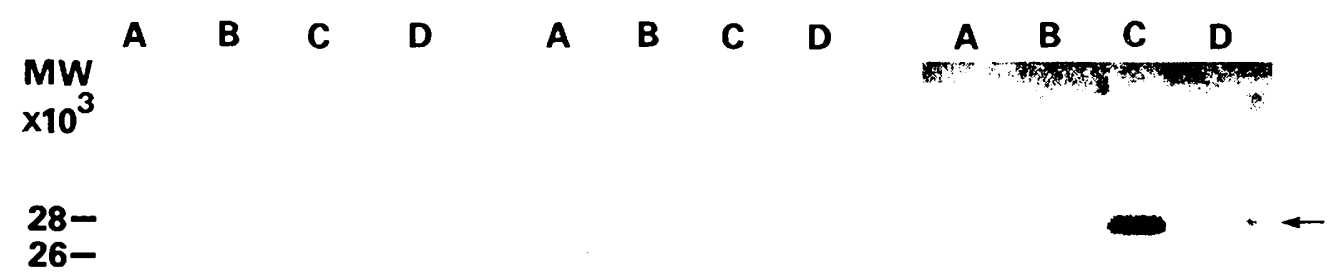

\section{8}

Fig. 4. Separation of nucleases from young peach leaves at different stages of senescence by electrophoresis and their activation by divalent cations, $\mathrm{Ca}^{2+}$ (left), $\mathrm{Mg}^{2+}$ (middle), and $\mathrm{Zn}^{2+}$ (right). A, Stage I. B, Stage II. C, Stage III. D), Stage IV. Details are given in Fig. lb.

or not detected. We therefore searched $\mathrm{Ca}^{2+}$, $\mathrm{Mg}^{2+}$ - and $\mathrm{Zn}^{2+}$-dependent nuclease activities in the peach leaves. Most nuclease activity required $\mathrm{Ca}^{2+}$ (mw. 18,000) and its activity was almost constant during the leaf growing period. $\mathrm{Mg}^{2+}$-dependent nuclease activity was not detected at any stage. We found that activation required $\mathrm{Zn}^{2+}$ (mw. 28,000) especially during Stage III (Fig. 4).

DNA in the cells of peach leaves may be completely resistant to $\mathrm{Ca}^{2+}$-dependent nuclease digestion, because its activity was detected at each stage of senescence. Instead, we found that most nucleases in peach leaves during senescence were $\mathrm{Zn}^{2+}$-dependent. The question therefore arises of how they become active during peach senescence. As Barton (1) suggested, senescence might be promoted by DNase liberated perhaps from lysosome-like organelles. It is suggested that $\mathrm{Zn}^{2+}$-dependent enzyme systems are important in the selective nature of hydrolysis associated with senescence. The present experiment, however, did not determine the properties of $\mathrm{Zn}^{2+}$ dependent nuclease in senescing peach leaves, although we are interested in the preferential destruction of DNA during senescence. Fur- ther study should make it possible to determine its function.

\section{Acknowledgement}

This work was partly supported by Grants 86-133 from the National Institute for Basic Biology.

\section{Literature Cited}

1. BARTON, R. 1966. Fine structure of mesophyll cells in senescing leaves of Phaseolus. Planta $71: 314-325$.

2. Boffey, S. A. and R. M. LeECH. 1982. Chloroplast DNA levels and the control of chloroplast division in light grown wheat leaves. Plant Physiol. 69: 1387-1391.

3. BURTON, K. 1956. The conditions and mechanism of the diphenylamine reaction for the colorimetric estimation of deoxyribonucleic acid. Biochem. J. 63: 315-323.

4. Butler, R. D. 1967. The fine structure of senescing cotyledons of cucumber. J. Exp. Bot. 18: $535-543$.

5. Ceriotri, G. 1955. Determination of nucleic acids in animal tissue. J. Biol. Chem. 214 : 59-70.

6. Coleman, A. W. 1979. Use of the fluorochrome 4'-6-diamidino-2-phenylindole in genetic and developmental studies of chloroplast 
DNA. J. Cell Biol. 82: 299-305.

7. DOdGE, J. D. 1970. Changes in chloroplast fine structure during the autumnal senescence of Betula leaves. Ann. Bot. 34:817-824.

8. FEller, U. K., T. T. SOONG and R. H. HAGEMAN. 1977. Leaf proteolytic activities and senescence during grain development of field-grown corn (Yea mays L.). Plant Physiol. 59: 290-294.

9. HURKMAN, W. J. 1979. Lltrastructural changes of chloroplasts in attached and detached, aging primary wheat leaves. Amer. J. Bot. $66: 64-70$.

10. IKEDA, T. and R. UEDA. 1964. Light-and electron microscope studies on the senescence of chloroplasts in Flodea leaf cells. Bot. Mag. Tokyo. 77: 336-341.

11. JAMES, T. W. and C. JOI'E. 1978. Visualization by fluorescence of chloroplast DNA in higher plants by means of the DNA-specific probe 4'-6-diamidino-2-phenylindole. J. Cell Biol. 79: 623-630.

12. Kar, R. K. and M. A. ChOudhuri. 1985. Senescence of Hydrilla leaves in light and darkness. Physiol. Plant. 63: 225-230.

13. KUMAR, K. B. and P. A. KHAN. 1983. Induction and suppression of RNase activity by growth regulators in senescing ragi leaves. Physiol. Plant. 58: 479-485.

14. Kurolwa, T. and T. Suzlki. 1980. An improved method for the demonstration of the in situ chloroplast nuclei in higher plants. Cell Struct. Func. 5: 195-197.

15. Kuroiwa, T., T. SuzuKI, K. OGaiva and S. KAWANO. 1981. The chloroplast nucleus: distribution, number, size, and shape, and a model for the multiplication of the chloroplast genome during chloroplast development. Plant Cell Physiol. 22: 381-396.

16. LEWINGTON, R. J., M. TALBot and E. W. SIMON. 1967. The yellowing of attached and detached cucumber cotyledons. J. Exp. Bot. 18: 526-534.

17. Lowry, O. H., N. J. Rosenbrough, A. L. FARR and R. J. RANDALL. 1951. Protein measurement with the folin phenol reagent. J. Biol. Chem. 193: 265-275.

18. LUTTKE, A. 1981. Heterogeneity of chloro. plasts in Acetabularia mediterranea. Heterogeneous distribution and morphology of chloroplast DNA. Exp. Cell Res. 131: 483488.

19. NAKAmura, S., S. Itoh and T. Kuroiwa. 1986. Behavior of chloroplast nucleus during chloroplast development and degeneration in Chlamydomonas reindarditi. Plant Cell
Physiol. $27: 775-784$.

20. Nishibayashi, S. and T. Kuroiwa. 1982. Behavior of leucoplast nucleoids in the epidermal cell of onion (Allium cepa) bulb. Protoplasma. 110: 177-184.

21. OGAWA, K. and T. KLrOIWA. 1985. Nuclease C: polymorphism of calcium-dependent nucleases in Chlamydomonas reindardtii. Plant Cell Physiol. 26: 481-491.

22. Peoples, M. B., V. C. Beilharz, S. P. WATERS, R. J. SIMPSON and M. J. DALLING. 1980. Nitrogen redistribution during grain growth in wheat (Triticum aestizum L.) II. Chloroplast scnescence and the degradation of ribulose-1, 5 -biphosphate carboxylase. Planta. 149: 241-251.

23. Ragetli, H. W., M. Weictralib and E. Lo. 1970. Degeneration of leaf cells resulting from starvation after excision. I. Electron microscopic observations. Can. J. Bot. 48 : 1913-1922.

24. REYNOI_DS, E. S. 1963. The use of lead citrate at high $\mathrm{pH}$ as an electron opaque stain in electron microscopy. J. Cell Biol. 17: 206 -212 .

25. ScotT, N. S. and J. V. POssingha.M. 1980. Chloroplast DNA in expanding spinach leaves. J. Exp. Bot. 31: 1081-1092.

26. SelldEN, ( 3 . and R. M. LeECH. 1981. Iocalization of DNA in mature and young wheat chloroplasts using the fluorescent probe 4'-6-diamidino-2-phenylindole. Plant Physiol. $68: 731-734$.

27. SilAW, M., P. K. BHATTACharya and WV. A. QLiCK. 1965. Chlorophyll protein, and nucleic acid levels in detached senescing wheat leaves. Can. J. Bot. 43: 739--746.

28. Shaw, M. and M. S. Monacha. 1965. Fine structure in detached, senescing wheat leaves. Can. J. Bot. 43: 747-755.

29. SPURR, A. R. 1969. A low viscosity epoxy resin embedding medium for electron microscopy. J. Ultrastructural Res. $26: 31-43$.

30. TyMMS, M. J., N. S. ScoT'T and J. V. PosSINGHAM. 1983. DNA content of Beta wulgaris chloroplasts during leaf cell expan. sion. Plant Physiol. 71: 785-788.

31. Wintermans, J.F. G. M. and D. A. Mots 1965. Spectrophotometric characteristics of chlorophylls and their pheophytins in ethanol. Biochim. Biophys. Acta. 109: 448-453.

32. WittenBACH, V. A. 1979. Ribulose bisphosphate carboxylase and proteolytic activity in wheat leaves from anthesis through senescence. Plant Physiol. 64: 884-887.

33. WitTENBACH, V. A., W. LiN and R. R. 
HERBERT. 1982. Vascular localization of proteases and degradation of chloroplasts in mesophyll protoplasts from senescing primary wheat leaves. Plant Physiol. 69: 98-102.

\title{
モモ葉の老化過程における葉緑体の微細構造之核樣体の変化
}

\author{
新居直祐 ${ }^{1} \cdot$ 河野重行 ${ }^{2} \cdot$ 中村宗一 $^{2} \cdot$ 黒岩常祥 ${ }^{2}$ \\ 1 名城大学農学部 468 名古屋市天白区 \\ 2 基礎生物学研究所 444 岡崎市明大寺町
}

\begin{abstract}
摘要
モモ葉の老化過程における佣状組織細胞の葉緑体の解 剖学的变化を透過型電子顕微鏡並びに螢光顕微鏡を用い て観察した。 また核様体（cp-DNA）の变化をタンパク 質, DNA, RNA 含量並びに nuclease 活性と関連づ て検討した，老化過程にある葉緑体では，チラュイドの 層状構造がゆるみ, そしてグラナ層数が減少して行った. この過程で, 葉緑体の大きさは正常細胞の葉緑体に比べ て小型化するとともに，しだいに球状化し，好才スミウ ム性顆粒数が増大した、完全に老化した細胞の葉緑体で は, 葉緑体包膜が破れ, 葉緑体の含有物質が細胞中に散 乱し，また内容物の確認できない数多くの小胞が観察さ

れた. 4'-6-diamidino-2-phenylindole (DAPI) による 䖝光顕微鏡法の観察結果から, 老化とともに cp-DNA は崩壊し，さらに枯死した葉では完全に消失することが 確認された. 老化過程での cp-DNA と葉緑体の崩壊は 細胞核の崩壊と関連していた。細胞中のタンパク質, DNA, RNA 含量は, 葉の黄化とともに明らかに低下し た.モ正葉の老化にともなう DNA 含量の低下と $\mathrm{Zn}^{2+}$ 依存の nuclease 活性が密接に関係しており, とくに Stage III (黄緑色葉) の段階で, その活性が最も高かっ た. いっぽら， $\mathrm{Ca}^{2+}$ 依存の nuclease 活性はもっとも高 かったが，老化過程を通じて変化が琹められなかった。
\end{abstract}

